\title{
Cold Acclimation and Alterations in Dehydrin-like and Bark Storage Proteins in the Leaves of Sibling Deciduous and Evergreen Peach
}

\author{
Rajeev Arora ${ }^{1}$ \\ Division of Plant and Soil Sciences, West Virginia University, Morgantown, WV 26506
}

Michael Wisniewski²

U.S. Department of Agriculture, Agriculture Research Service, Appalachian Fruit Research Station, Kearneysville, WV 25430

\author{
Lisa J. Rowland ${ }^{3}$ \\ U.S. Department of Agriculture, Agriculture Research Service, Fruit Laboratory, Beltsville, MD 20705
}

Additional index words. peach, Prunus persica, cold acclimation, freezing tolerance, dehydrin, bark storage protein

\begin{abstract}
Seasonal changes in cold tolerance and proteins were studied in the leaves of sibling deciduous and evergreen peach [Prunus persica $(\mathrm{L}$.$) Batsch]. Freezing tolerance [defined as the subzero temperature at which 50 \%$ injury occurred $\left(\mathbf{L T}_{50}\right)$ ] was assessed using electrolyte leakage. Proteins were separated by sodium dodecyl sulfate polyacrylamide-gel electrophoresis. Electroblots were probed with anti-dehydrin and anti-19-kD peach bark storage protein (BSP) antibodies. Leaf $\mathrm{LT}_{50}$ decreased successively from $-5.8^{\circ} \mathrm{C}$ on $18 \mathrm{Aug}$. to $-10.3^{\circ} \mathrm{C}$ in the evergreen genotype and from $-7.0{ }^{\circ} \mathrm{C}$ to $-15.0{ }^{\circ} \mathrm{C}$ in the deciduous genotype by $14 \mathrm{Oct}$. Protein profiles and immunoblots indicated the accumulation of a 60 - and 30-kD protein during cold acclimation in the leaves of deciduous trees; however, levels of these proteins did not change significantly in the evergreen trees. Immunoblots indicate that the $60-\mathrm{kD}$ protein is a dehydrin-like protein. Gelelectrophoresis and immunoblots also indicated that the 19-kD BSP progressively disappeared from summer through fall in leaves of deciduous peach but accumulated to a high level in bark tissues. A similar inverse relationship was not evident in evergreen peach.
\end{abstract}

Many plants exhibit an increase in freezing tolerance (FT) when exposed to low, nonfreezing temperatures (Levitt, 1980). This change in tolerance involves several physiological changes in the tissue, including altered gene expression (Guy, 1990). Most studies with deciduous woody plants, particularly fruit trees, have focused on investigating cold acclimation in bark and xylem tissues as well as overwintering buds (Ashworth and Wisniewski, 1991; Wisniewski and Arora, 1993). To our knowledge, no study has been conducted investigating the ability of leaves of deciduous fruit trees to cold acclimate under natural conditions. In this regard, the existence of sibling deciduous and evergreen peach genotypes (Arora et al., 1992; Arora and Wisniewski 1994; Rodriguez-A et al., 1994) provides a good model system for evaluating and comparing the cold acclimation potential of leaves from two related genotypes that differ in cold hardiness (Arora et al., 1992). In contrast to deciduous peach that undergoes endodormancy in fall, evergreen peach retains its leaves and continues terminal growth under favorable conditions (Arora et al., 1992). Our previous work with these genotypes has demonstrated a distinct pattern of accumulation and turnover of a putative $19-\mathrm{kD}$ bark storage protein (BSP) (Arora et al., 1992) and the accumulation of peach cold acclimation protein of $60 \mathrm{kD}$ (PCA 60) in the bark tissues of the two genotypes ( Arora and Wisniewski, 1994).

Received for publication 6 Feb. 1996. Accepted for publication 20 May 1996. West Virginia Univ. Agricultural Expt. Station scientific article no. 2543. The cost of publishing this paper was defrayed in part by the payment of page charges. Under postal regulations, this paper therefore must be hereby marked advertisement solely to indicate this fact.

${ }^{1}$ Assistant professor; to whom reprint requests should be addressed.

${ }^{2}$ Plant physiologist.

${ }^{3}$ Research geneticist.
Since the evergreen genotype retains its leaves, it also was of interest to examine cold acclimation in these tissues. Our study was undertaken to evaluate changes in FT of leaves of deciduous and evergreen peach genotypes from summer to fall. Protein studies on leaf tissue were conducted to determine whether the $60-\mathrm{kD}$, dehydrin-like protein (PCA 60) was present and associated with cold acclimation in these tissues. Additionally, an attempt was made to examine the relationship between the patterns of accumulation of the 19-kD BSP in the leaf and bark tissues of deciduous and evergreen peach from summer to fall.

\section{Materials and Methods}

Plant material. Fully expanded, uniformly sized leaves from current-year shoots of 4- to 5-year-old sibling deciduous and evergreen peach trees (Arora et al., 1992; Rodriguez-A et al., 1994) were collected biweekly (starting on 18 Aug.) at the Appalachian Fruit Research Station, Kearneysville, W.Va. The samples were collected in the field, packed on ice, and brought to the laboratory where they were processed for FT determinations and protein extraction. Bark tissues were collected monthly (starting 20 Aug.) from current-year shoots and prepared for protein extractions as previously described by Arora et al. (1992).

FT determination. FT was determined by modifying the protocol of Steffen et al. (1989). Leaf disks (ranging from 15 to $20 \mathrm{~mm}$ in diameter) were prepared using a no. 9 or 12 cork borer (as required). Leaf margins and midribs were excluded from the disks. Disks were rinsed briefly and placed in $25 \times 200-\mathrm{mm}$ test tubes (one disk per tube and three tubes per treatment temperature), which were then placed in a controlled-temperature glycol bath (model 2325; Forma Scientific, Marietta, Ohio) at $0{ }^{\circ} \mathrm{C}$. After 15 min, the bath temperature was lowered to $-1{ }^{\circ} \mathrm{C}$ and held there until 
tissue temperature reached $-1^{\circ} \mathrm{C}$. Tissue temperature was monitored with copper-constantan thermocouples (TT-T-30; Omega Engineering, Stamford, Conn.) connected to a digital thermometer (DP 465; Omega Engineering, Stamford, Conn.). Ice nucleation then was initiated by dropping ice crystals in each tube and samples were held at $-1.0^{\circ} \mathrm{C}$ for an additional $30 \mathrm{~min}$ after tissue temperature returned to $-1^{\circ} \mathrm{C}$. The temperature then was lowered at $0.5^{\circ} \mathrm{C}$ every $30 \mathrm{~min}$ to $-2{ }^{\circ} \mathrm{C}, 1^{\circ} \mathrm{C}$ every $30 \mathrm{~min}$ to $-6^{\circ} \mathrm{C}$, and $2^{\circ} \mathrm{C}$ every 30 min thereafter. Tubes were removed at selected temperatures and thawed on ice overnight. Controls were kept on ice throughout this period. FT [the subzero temperature at which $50 \%$ injury occurred $\left(\mathrm{LT}_{50}\right)$ ] of leaf tissue was determined by ion leakage measurements as previously described by Arora et al. (1992). During our study, first measurements of FT during summer were made with leaves collected on 18 Aug., hence these samples were treated as nonacclimated.

Protein extraction. Soluble proteins from leaves were extracted by grinding tissues in a prechilled mortar with Tris buffer $(0.1 \mathrm{M}$ Tris-HCl, pH 9.5, containing $1 \mathrm{~mm}$ PMSF) (Houde et al., 1992). The extract was centrifuged at $26,000 \times \mathrm{g}$ for $1.5 \mathrm{~h}$. The resultant supernatant was filtered through a $0.4-$ and $0.22-\mu \mathrm{m}$ filter, respectively, and assayed for protein content by a modified Bradford assay (Ramagl and Rodriguez 1985). Bark proteins were isolated as described by Arora et al. (1992).

Sample preparation. Samples were prepared and discontinuous sodium dodecyl sulfate polyacrylamide-gel electrophoresis (SDSPAGE) was performed with a PROTEAN II electrophoresis unit (Bio-Rad, Hercules, Calif.) as described by Arora et al. (1992). Gels were stained with Coomassie Brilliant Blue G-250 using the procedure of Neuhoff et al. (1988).

Preparation of anti-19 kD antibody and immunoblotting. For the production of $19-\mathrm{kD}$ BSP antiserum, soluble proteins were extracted from the pooled bark tissues collected from deciduous peach trees in December, January, and February. Our previous work indicated that bark tissues were highly enriched in $19-\mathrm{kD}$ BSP during these months (Arora et al., 1992). About $8.5 \mathrm{mg}$ of total soluble proteins was fractionated by SDS-PAGE as described elsewhere (Arora et al., 1992). After briefly staining with Coomassie blue and destaining, the $19-\mathrm{kD}$ bands (which contained $\approx 1.0 \mathrm{mg}$ of $19-\mathrm{kD}$ polypeptide based on visual estimates) were excised, quickly rinsed in water, and stored at $-80^{\circ} \mathrm{C}$. The gel slices then were used for custom preparation of polyclonal BSP antiserum in rabbits (Organan Teknica, West Chester, Pa.). Pre-immune serum was taken from the rabbits before the immunization and immune serum was collected 2 weeks after the second and subsequent injections. Anti-dehydrin antiserum (provided by T. Close) was directed against a synthetic peptide of a 15 amino acid consensus sequence (EKKGIMDKIKEKLPG) that is highly conserved at the Cterminus of dehydrin proteins from several plant species (Close et al., 1993a). For immunoblotting, proteins were electroblotted onto $0.45-\mu \mathrm{m}$ nitrocellulose (Schleicher \& Schuell, Keene, N.H.) and probed with $1: 1000$ and 1:2000 dilutions of anti-dehydrin and anti19-kD BSP antisera, respectively, as described by Arora and Wisniewski (1994).

\section{Results}

FT. FT ( $\left.\mathrm{LT}_{50}\right)$ of nonacclimated (on 18 Aug.) leaf tissue of evergreen and deciduous genotypes was -5.8 and $-7^{\circ} \mathrm{C}$, respectively (Table 1). Leaf cold hardiness in both genotypes increased in successively later sampling periods. There was an early increase $(23 \%)$ in the cold hardiness of leaves of the deciduous genotype between $18 \mathrm{Aug}$. and 1 Sept. In contrast, there was no change in the
Table 1. Freezing tolerance $\left(\mathrm{LT}_{50}\right)^{\mathrm{z}}$ of leaves of sibling deciduous and evergreen peach genotypes from 18 Aug. through 23 Oct.

\begin{tabular}{lcc}
\hline \hline Sampling & \multicolumn{2}{c}{$\mathrm{LT}_{50}\left({ }^{\circ} \mathrm{C}\right)$} \\
\cline { 2 - 3 } date & Evergreen & Deciduous \\
\hline 18 Aug. & $-5.8 \pm 0.24$ & $-7.0 \pm 0.16$ \\
1 Sept. & $-5.7 \pm 0.24$ & $-8.6 \pm 0.63$ \\
14 Sept. & $-7.4 \pm 0.30$ & $-10.0 \pm 0.46$ \\
28 Sept. & $-7.8 \pm 0.29$ & $-10.2 \pm 0.7$ \\
14 Oct. & $-10.3 \pm 0.2$ & $-15.0 \pm 0.7$ \\
23 Oct. & $9.7 \pm 0.7$ & ---
\end{tabular}

${ }^{\mathrm{z}} \mathrm{LT}_{50}$ was determined using the following expression: percent injury $=$ [percent $\mathrm{L}_{(\mathrm{t})}$ - percent $\mathrm{L}_{(\mathrm{c})} \div 100$ - percent $\mathrm{L}_{(\mathrm{c})}$ ] $\times 100$, where percent $\mathrm{L}_{(\mathrm{t})}$ and percent $\mathrm{L}_{(\mathrm{c})}$ are the measurements of percent ion leakage for the respective freezing treatment temperatures and unfrozen control, respectively. $\mathrm{LT}_{50}$ was defined as the subzero temperature at which $50 \%$ injury occurred. Values are means of three separate measurements \pm SE.

leaf hardiness of evergreen peach during the same period. On 14 Oct., $\mathrm{LT}_{50}$ values for evergreen and deciduous genotypes were -10.3 and $-15^{\circ} \mathrm{C}$, respectively. This result indicates about two-fold higher cold acclimation capacity $(\triangle \mathrm{FT}$; acclimated FT - nonacclimated FT, taking into account absolute values) ( Stone et al., 1993) in the deciduous genotype compared to the evergreen $\left(\Delta \mathrm{FT}\right.$ of $8^{\circ} \mathrm{C}$ in deciduous vs. $4.6^{\circ} \mathrm{C}$ in evergreen) (Table 1). After 14 Oct., no further FT measurements were made for deciduous trees because by 29 Oct. most leaves in these trees had partially yellowed and some had begun to abscise. However, although no such leaf discoloration was evident in evergreen trees, their leaves did not exhibit any further acclimation by 23 Oct. (Table 1). FT of leaves of two genotypes was not determined after 23 Oct.

$S D S-P A G E$. In general, there was an accumulation in the leaves of several polypeptides, with sizes ranging from 30 to $106 \mathrm{kD}$ with cold acclimation in the deciduous genotype. Along with the accumulation of a 55-kD polypeptide, which constituted a major portion of the total protein and most likely represents the large subunit of RUBISCO, an accumulation of a $60-\mathrm{kD}$ polypeptide and disappearance of a $19-\mathrm{kD}$ polypeptide was noted in the coldacclimated tissues of the deciduous genotype (Fig. 1A). Additionally, a $30-\mathrm{kD}$ polypeptide also accumulated in the deciduous genotype during cold acclimation. In the evergreen genotype, however, there was no change in the pattern of the $19-$ and $30-\mathrm{kD}$ polypeptides, and the band intensity of the $60-\mathrm{kD}$ polypeptide in these tissues decreased somewhat during cold acclimation (Fig. 1A). Western blots indicated that the $19-\mathrm{kD}$ polypeptide in leaf tissue is related immunologically to $19-\mathrm{kD}$ peach BSP (Fig. 1B). The $60-\mathrm{kD}$ polypeptide appears to be immunologically related to synthetic dehydrin peptide (Fig. 1C). The $60-\mathrm{kD}$ protein on the immunoblot was only evident in the cold-acclimated deciduous leaves and nonacclimated leaves of evergreen peach. In the other samples, only a faint band was visible (visible only on the original immunoblots). Even when present, the level of the $60-\mathrm{kD}$ dehydrinlike protein were low compared to its accumulation in other peach tissues during cold acclimation (Arora and Wisniewski, 1994; Arora et al., 1992). Probing with pre-immune serum did not result in any immune complex with either antibody (data not shown).

The SDS-PAGE profile of bark proteins indicates the gradual accumulation of a 19-kD polypeptide from August through December in the deciduous genotype (Fig. 2A). It was barely detectable in summer (August) but was present at high levels in the fall and winter, at which time it constituted a major portion of total bark proteins. In the evergreen genotype, however, the increase in 19$\mathrm{kD}$ polypeptide during fall and winter was less dramatic compared 
to the deciduous genotype in that it was detectable in summer and accumulated to comparatively much lower levels in winter (Fig. 2A). Immunoblot analysis indicates that the $19-\mathrm{kD}$ polypeptide in bark tissue is immunologically cross reactive with the antibody raised against 19-kD BSP and follows the same seasonal pattern as exhibited by SDS-PAGE (Fig. 2B). Immunoblot data also indicate an excessive staining of December samples of deciduous peach, which may be due to the complex formation between colordeveloping reagents of the western blot kit and interfering nonproteinaceous compounds in winter samples. A similar increase in nonproteinaceous staining also was evident in the Coomassie stained gels (Fig. 2A). Probing with pre-immune serum did not result in any immune complexes (data not shown).

\section{Discussion}

$F T$. Our results indicate that leaves of deciduous and evergreen peach genotypes have the capacity to cold acclimate during fall as revealed by increases in FT (Table 1). Leaves of deciduous trees, collected from 18 Aug. to 28 Sept., exhibited 1.6-fold greater increase in FT compared to evergreen genotypes $\left(\Delta \mathrm{FT}\right.$ of $\left.3.2 \mathrm{vs} .2 .0^{\circ} \mathrm{C}\right)$. This increase in FT in deciduous trees may be in response to shorter photoperiods (13.5 h on Aug. 18 vs. $11.75 \mathrm{~h}$ on Sept. 28); however, subsequent increases in FT may have been due to shorter photoperiods and colder temperatures. Pre-

vious studies (Fuchigami et al., 1971; Irving and Lamphear 1967) have indicated that, in nature, cold acclimation in deciduous perennials is a two-stage process. The first stage (initial increase in FT) is induced by short days, while the second stage is induced primarily by low temperatures (Sakai and Larcher 1987). In contrast to the deciduous genotype, evergreen peach appears to be less responsive to shorter photoperiods as indicated by the absence of an increase in FT during 18 Aug. through 1 Sept. and only about five-eighths as much of an increase in FT by 28 Sept. compared to the deciduous peach. Although the data are not definitive because acclimation was not determined under a controlled photoperiod, temperature conditions, or both, our results are consistent with those from our previous study where a similar pattern of cold acclimation of bark tissues was observed in these genotypes (Arora et al, 1992).

This study demonstrates that in a deciduous tree, leaves can cold acclimate in the fall before leaf abscission. Durham et al.
DECIDUOUS EVERGREEN NA CA NA CA

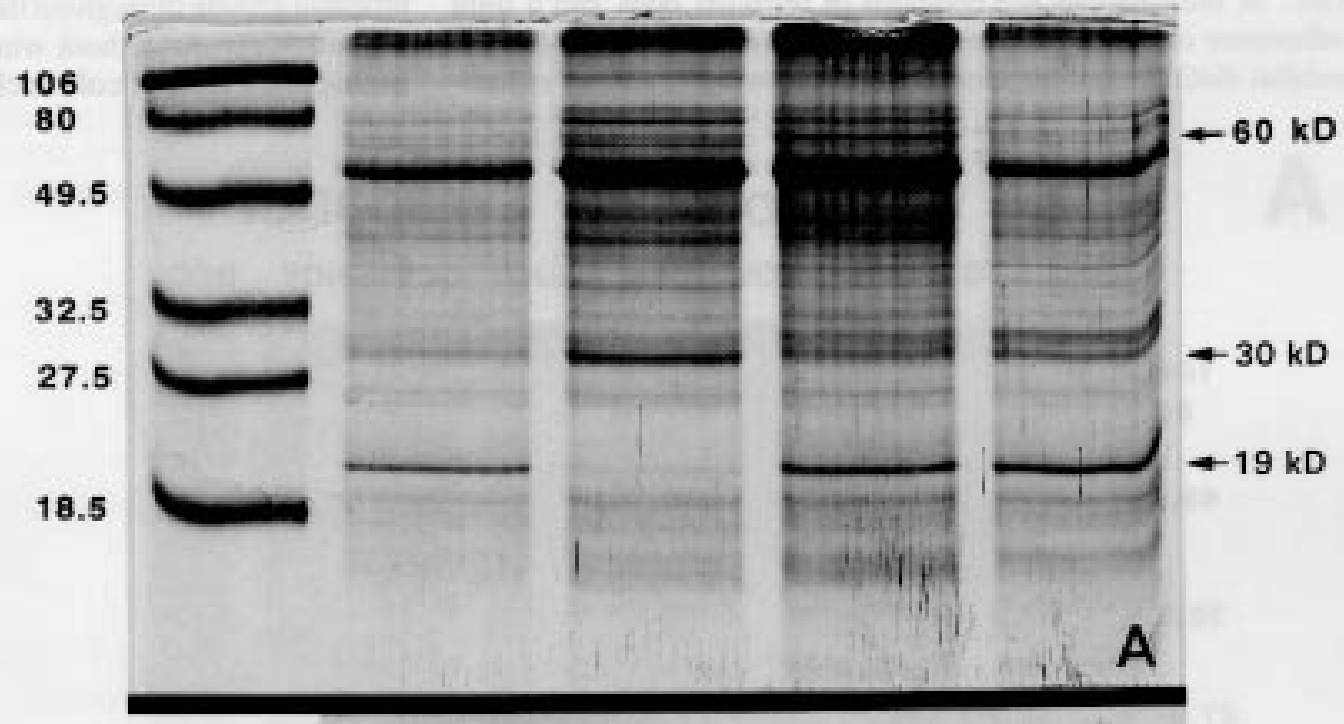

. Accumulation kinetics of $19-\mathrm{kD}$ bark storage protein and $60-\mathrm{kD}$ dehydrin protein in the nonacclimated (18 Aug.) and cold-acclimated (14 Oct.) leaf tissue of deciduous and evergreen peach genotypes. (A) Coomassie blue-stained gel, $45 \mu \mathrm{g}$ protein per lane. (B and $\mathbf{C}$ ) Parallel gels ( $5 \mu \mathrm{g}$ protein per lane) transferred to nitrocellulose membranes and probed with anit-19-kD antiserum and antidehydrin antiserum, respectively. $\mathrm{NA}=$ nonacclimated and $\mathrm{CA}=$ cold acclimated.

(1991) noted a cold acclimation ability of leaves of trifoliate orange (Poncirus trifoliata), a plant that is normally deciduous in winter; however, cold acclimation in the orange leaves was induced by exposing 6-week-old seedlings to $5{ }^{\circ} \mathrm{C}$ for 7 weeks in growth chambers. Moreover, the deciduous nature of these seedlings did not become apparent until they were 16 weeks old. Important to our study is that leaves of evergreen peach also exhibit considerable cold acclimation potential (Table 1), suggesting its potential use as an ornamental woody perennial in milder, yet frost-prone areas. Recognition of cold acclimation ability in the leaves of deciduous and evergreen peach also may have important implications for efforts to improve the cold hardiness of evergreen peach genetically.

Our data indicate that leaves of the deciduous genotype acclimate sooner and to a greater extent $\left(\Delta \mathrm{FT}\right.$ of $8^{\circ} \mathrm{C}$ by 14 Oct.) than they do in the evergreen genotype ( $\Delta \mathrm{FT}$ of $4.5^{\circ} \mathrm{C}$ by $14 \mathrm{Oct}$.) (Table 1). This may be associated with the response to photoperiod 
and the cessation of growth, which are apparently lacking in the evergreen genotype (Arora et al., 1992; Rodriguez-A et al., 1994). Although, deciduous trees were well into endodormancy by 14 Oct., as indicated by the presence of terminal buds and a tight adherence of bark to the underlying xylem, most leaves did not exhibit distinct signs of senescence (yellowing or loss of chloro- phyll) and abscission. If senescence was evident, those leaves were not included in the study. However, the evergreen genotype, which also had cold acclimation capacity (Table 1), continued to exhibit terminal growth throughout the entire sampling period, continuing intermittently throughout winter. Results from this study on the timing and extent of cold acclimation in these genotypes support
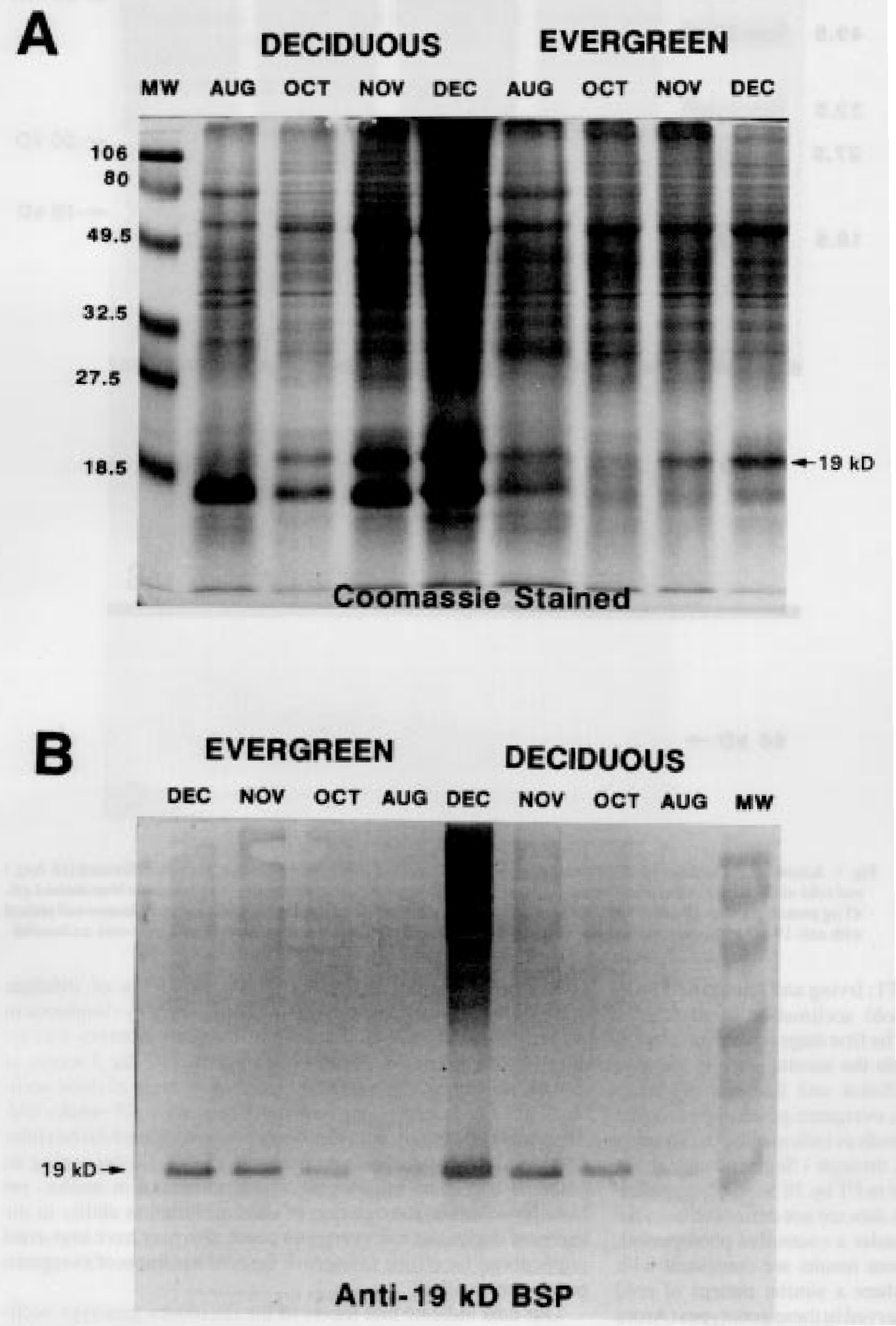

Fig. 2. Seasonal variation in the accumulation of $19-\mathrm{kD}$ peach bark storage (BSP) protein in the bark tissues of deciduous and evergreen genotypes. (A) Coomassie blue-stained gel; $30 \mu \mathrm{g}$ of protein was loaded per lane. (B) Parallel gel (5 $\mu \mathrm{g}$ protein per lane) transferred to nitrocellulose and probed with anti-19-kD BSP antiserum. our earlier conclusions (Arora et al., 1992) that although cessation of growth may be a prerequisite for attaining maximum hardiness, it is not an absolute requirement for cold acclimation to occur. This is consistent with the findings of Durham et al. (1991) who noted cold acclimation ability in trifoliate orange (Poncirus trifoliata) seedlings without it becoming deciduous.

SDS-PAGE and immunoblots. Coomassie-stained gels and immunoblots indicate accumulation of a 60 - and $30-\mathrm{kD}$ protein in the leaves from deciduous peach trees. Although the identity of the $30-\mathrm{kD}$ protein is unknown, the $60-\mathrm{kD}$ protein is most likely related to the PCA 60 dehydrin-like protein previously characterized in peach bark and xylem tissues (Arora and Wisniewski, 1994, 1996). This conclusion is based on the similarity in apparent molecular mass and the immunological reactivity of the $60-\mathrm{kD}$ leaf protein with dehydrin antibody (Fig. 1C). However, the accumulation of $60 \mathrm{kD}$ protein in leaf tissue was not as strong during cold acclimation as in other peach tissues (Arora and Wisniewski, 1994, 1996). The reason for this result is unclear but has been observed in another study using leaf tissue of these two peach genotypes (T. Artlip, personal communication).

In contrast to deciduous peach, the $60-\mathrm{kD}$ leaf protein was not associated with cold acclimation in leaves of the evergreen peach (Fig. $1 \mathrm{~A}$ and C). On the contrary, it appears to decrease during cold acclimation. The reason for this anomaly is not clear; however, our results suggest that stressrelated proteins other than PCA 60 may be responsible for cold acclimation in leaf tissues of peach. This hypothesis remains to be determined. The presence of PCA 60 in nonacclimated leaf tissues of the evergreen genotype may have been in response to 
dehydration stress experienced by these trees due to a relatively higher water demand. As previously stated, unlike deciduous peach, the evergreen genotype does not enter endodormancy and continues to grow actively year round under favorable environmental conditions.

Dehydrin-like polypeptides of 65,60 , and $14 \mathrm{kD}$, first identified in floral buds of blueberry, also have been induced in leaves by a 2 -week treatment at $4{ }^{\circ} \mathrm{C}$ (Muthalif and Rowland, 1994). Recently, a cDNA clone of PCA 60 has been identified and sequenced, and the gene transcript was up-regulated during cold acclimation (T. Artlip, personal communication). This protein belongs to the D-11 subfamily of late embryogenesis abundant proteins, also called "dehydrins" (Close et al., 1993b). Our data indicate, however, that PCA 60 is only weakly present in leaf tissues during cold acclimation of the deciduous genotype and not present at all in the evergreen genotype that also cold acclimated. This suggests that cold acclimation in these tissues may have been due to factors, such as water status of the tissue, other than just the presence of PCA 60.

Seasonal pattern of leaf and bark proteins of the deciduous genotype indicate that as the leaf $19-\mathrm{kD}$ protein decreases, $19-\mathrm{kD}$ protein in bark tissues increases (compare Figs. 1A and 2A). Immunoblot analyses indicate that the $19-\mathrm{kD}$ polypeptide in leaf is immunologically related to a $19-\mathrm{kD}$, putative BSP (Figs. 1B and 2B). This inverse pattern of $19-\mathrm{kD}$ accumulation may be explained, in part, by altered source-sink status of the plant. In summer, expanding leaves may serve as a $\mathrm{N}$ sink and contain high levels of $19-\mathrm{kD}$ polypeptide, which in fall (as leaves senesce and abscise), may become a $\mathrm{N}$ source for $19-\mathrm{kD}$ polypeptide accumulating in bark tissues. This view, although consistent with our data, is speculative and more detailed study is warranted to support or disprove it. It is important to note, however, that an altered sourcesink relationship has been implicated in triggering a 32-kD BSP expression in bark tissues of poplar (Coleman et al., 1991). The inverse relationship of accumulation of the $19-\mathrm{kD}$ polypeptide in the leaves and bark tissues of the evergreen genotype was not detected. Unlike deciduous genotype, apical growth in evergreen peach continues under favorable conditions throughout the year, and lateral leaves remain firmly attached to twigs until December (Arora et al., 1992; Rodriguez-A et al., 1994). This conclusion would suggest that leaves of evergreen peach may continue to act as sink, rather than source, until late in the season.

\section{Literature Cited}

Arora, R. and M.E. Wisniewski. 1994. Cold acclimation in genetically related (sibling) deciduous and evergreen peach (Prunus persica [L.] Batsch). II. A 60-kilodalton bark protein in cold acclimated tissues of peach is heat-stable and related to the dehydrin family of proteins. Plant Physiol. 105:95-101.

Arora, R. and M.E. Wisniewski. 1996. Accumulation of 60-kD dehydrin protein in peach xylem tissues and its relationship to cold acclimation. HortScience. (In press.)

Arora, R., M.E. Wisniewski, and R. Scorza. 1992. Cold acclimation in genetically related (sibling) deciduous and evergreen peach (Prunus persica $[\mathrm{L}$.] Batsch). I. Seasonal changes in cold hardiness and polypeptides of bark and xylem tissues. Plant Physiol. 99:1562-1568.

Ashworth, E.N. and M.E. Wisniewski. 1991. Response of fruit tree tissues to freezing temperatures. HortScience 26:501-504.

Close, T.J., R.D. Fenton, and F. Moonan. 1993a. A view of plant dehydrins using antibodies specific to the carboxy terminal peptide. Plant Mol. Biol. 23: 279-286

Close, T.J., R.D. Fenton, A. Yang, R. Asghar, D.A. DeMason, D.E. Crone, N.C. Meyer, and F. Moonan. 1993b. Dehydrin: The protein, p. 104-114. In: T.J. Close and E.A. Bray (eds.). Plant responses to cellular dehydration during environmental stress. Current topics in plant physiology: An American Society of Plant Physiologists Ser., Rockville, Md.

Coleman, G.D., T.H.H. Chen, S.G. Ernst, and L. Fuchigami. 1991. Photoperiod control of poplar bark storage protein accumulation. Plant Physiol. 96: 686-692.

Durham, R.E., G.A. Moore, D. Haskell, and C.L. Guy. 1991. Coldacclimation induced changes in freezing tolerance and translatable RNA content in Citrus grandis and Poncirus trifoliata. Physiol. Plant. 82:519522.

Fuchigami, L.H., C.J. Weiser, and D.R. Evert. 1971. Induction of cold acclimation in Cornus stolonifera Michx. Plant Physiol. 47:98-103.

Guy, C.L. 1990. Cold acclimation and freezing stress tolerance: Role of protein metabolism. Annu. Rev. Plant Physiol. Plant Mol. Biol. 41:187223.

Houde, M., R.S. Dhindsa, and F. Sarhan. 1992. A molecular marker to select for freezing tolerance in Gramineae. Mol. Gen. Genet. 234:43-48.

Irving, R.M. and F.O Lamphear. 1967. A long day leaf as a source of cold hardiness inhibitors. Plant Physiol. 42:1384-1388.

Levitt, J. 1980. Response to plant environmental stresses. Chilling, freezing and high temperature stresses. 2nd ed. Academic, New York. Muthalif, M.M. and L.J. Rowland. 1994. Identification of dehydrin-like proteins responsive to chilling in floral buds of blueberry. Plant Physiol. 104:1439-1447.

Neuhoff, V.N., D.T. Arnold, D. Tanbe, and W. Elrhardt. 1988. Improved staining of proteins in polyacrylamide gels including isoelectric focusing gels with clear background at nanogram sensitivity using Coomassie brilliant blue G-250 and R-250. Electrophoresis 9:255-262.

Ramagl, L.S. and I.V. Rodriguez. 1985. Quantification of microgram amounts of protein in two-dimensional polyacrylamide gel electrophoresis sample buffer. Electrophoresis 6:559-563.

Rodriguez-A, J., W.B. Sherman, R. Scorza, M.E. Wisniewski, and W.R. Okie. 1994. 'Evergreen' peach, its inheritance and dormant behavior. J. Amer. Soc. Hort. Sci. 119:789-792.

Sakai, A. and W. Larcher. 1987. Frost survival of plants: Responses and adaptation to freezing stress. Ecological studies. vol. 62. SpringerVerlag, Berlin.

Steffen, K.L., R. Arora, and J.P. Palta. 1989. Sensitivity of photosynthesis and respiration to a freze-thaw stress: Role of realistic freeze-thaw protocol. Plant Physiol. 89:1372-1379.

Stone, J.M., J.P. Palta, J.H. Bamberg, L.S. Weiss, and J.F. Harbage. 1993. Inheritance of freezing resistance in tuber-bearing Solanum species: Evidence for independent genetic control of nonacclimated freezing tolerance and cold acclimation capacity. Proc. Natl. Acad. Sci. USA. 90:7869-7873.

Wisniewski, M. and R. Arora. 1993. Adaptation and response of fruit trees to freezing temperatures, p. 299-320. In A.R. Biggs (ed.). Cytology, histology, and histochemistry of fruit tree diseases. CRC Press, Boca Raton, Fla. 